\title{
The Marginalization of the Igbo People in Nigeria's Political and Economic Sectors: What Is the Way Forward?
}

\author{
Ezeakukwu Emmanuel Nsoedo \\ National Open University of Nigeria (NOUN), Abuja, Nigeria \\ Email: legwoent@yahoo.com
}

How to cite this paper: Nsoedo, E.E. (2019) The Marginalization of the Igbo People in Nigeria's Political and Economic Sectors: What Is the Way Forward? Open Journal of Social Sciences, 7, 427-437. https://doi.org/10.4236/jss.2019.77035

Received: June 19, 2019

Accepted: July 28, 2019

Published: July 31, 2019

Copyright (อ 2019 by author(s) and Scientific Research Publishing Inc. This work is licensed under the Creative Commons Attribution International License (CC BY 4.0).

http://creativecommons.org/licenses/by/4.0/

\section{(c) (i) Open Access}

\begin{abstract}
This study looked into the marginalization of the Igbo people primarily from the political and economic perspectives; albeit, the social factors were also evaluated to appreciate if the title could be justified. The researcher gave historical consideration to the pre-civil war of 1967, and post-civil war with regard to the economic and political status occupied by the Eastern region when compared to the Northern and Western regions. The Eastern region was found to be a leader in economic advancement beyond the shores of Nigeria. Politically, it played pivotal roles through the political leaders of the regional powerhouse, the NCNC. Following the end of the Nigeria Biafra civil war, the military regimes introduced series of decrees that ushered in policies which did not accommodate the interest of the Igbo people, such as unfulfilled reconstruction of the devastated Igbo land, 20 pounds flat refund policy, indigenization decree, etc. The punitive economic disadvantages appeared to have persisted years after the civil war. The airports from the Southeast lacked quality infrastructure despite having very significant Igbo travelers dominating this sector. The study used historical research analysis approach by examining multiple sources such as archived materials, books, journals, and newspapers. The researcher provided recommendations to steps towards restructuring, or an integrated regional development to counter development inertia.
\end{abstract}

\section{Keywords}

Marginalization, Political, Economic, Civil War, Igbo, Decree, Policies

\section{Introduction}

The Igbo race continues to face enormous political and economic challenges 
since the instigated and imposed civil war. A plain glance at the economic and political development in Nigeria may be considered normal in terms of where the Igbo people stand politically, especially economically when compared to other ethnic nationalities. Indeed a cursory look at the poverty level among the ethnic groups would make the Igbo race appear exceptionally successful.

The Igbo people in reality experienced an overwhelming level of disadvantages based on public policies that seemed crafted to undermine their ability to maximize political and economic potentials. The restructuring of Nigeria to create more states for the northern states to the detriment of the Southern Nigeria, especially, the Southeast was not only an impediment politically; it impacts the economic potentials of the Igbo people negatively. Such policies as the failure to rehabilitate the Biafra land after the war, the 20 pounds flat refund to any Biafran who wished to convert the old currency, or deposits with banks prior to the war; the Nigerian Enterprises Promotion Decree of 1972, also known as Indigenization Decree, Federal Character Principle, manipulated population census, creation of states and local government areas in favor of the Northern Nigeria, deliberate underuse of seaports within the Igbo axis, lack of standard international airport, and other exploitative actions. These formed many overt and indirect actions to diminish the ability of the Igbo people to compete on a level-playing ground with other major ethnic groups.

Unlike today where some political actors will dare the Igbo people to vote against their aspirations, and perhaps, would still go ahead to win whether the Igbo people voted for them or not. It was not like that during the fight for the country's independence from the British colonial masters, and neither was that way during the first republic. The Eastern region used to play a very significant role politically in determining which parties collaborated to form a government. The National Council of Nigeria and Cameroun, which later changed to National Council of Nigerian Citizens (NCNC) under the leadership of Dr Nnamdi Azikiwe partnered with the Northern People's Congress founded by Tafawa Balewa to form the government (University of Central Arkansas, 2019) [1]. Tafawa Balewa was appointed the Prime Minister and Nnamdi Azikiwe was made the Head of State (University of Central Arkansas, 2019) [1].

Economically, every region was autonomous, and developing at its pace's ability. The Information Service (1956) [2] reported that the Eastern region economy was heavy palm produce, through which palm kernels were exported to earn foreign exchange, as well as palm frond is used for roofing, and palm wine for drinking. The Eastern region government promoted systematic agricultural economy, including farm settlements; cash crops such as rubber, cocoa, and palm grove scheme were established, creating an opportunity for people to earn a living through farming (Ministry of Commerce, 1966) [3].

The coal industry was thriving under Nigeria Railway Corporation, and $\mathrm{Ni}$ gersteel's rolling mill which produces mild steel bars were among only a few such operations in West Africa (Information Service, 1956) [2]. The NCNC led-government established a cement factory at Nkalagu, the Nigeria Breweries 
set up a stout factory at Aba, while in Port Harcourt, a Tobacco and glass making plant was sited there (Van Buer, 1968) [4]. "Oil mining in the region started by Shell D’Archy in 1937 did not yield commercial quantities until 1957. But by 1965, oil was a promising source of income" (Van Buer, 1968, p. 23) [4].

Having appraised the background to the phenomenon that prompted this study, the researcher will look at some of the antecedents of the Igbo people within the economic and political realm before 1967, and the prevailing condition in the present Nigeria. It is the hope of the researcher that the outcome of this study will be beneficial to the scholars, policymakers, and Nigerians, etc. as well as, add to the body of literature.

\section{Problem Statement}

The NCNC led-government equally encouraged community self-help as a means of constructing laterite and earth-based roads for transportation within villages and inter-cities to ensure free movement of people and goods. This is a common trait among Igbo communities when they come together to provide services that governments had neglected to render to them. By 1955, the Ministry in charge of Community Development had cleared about 13,000 km (8000 miles) of roads, of which less than 10\% were tarred (Information Service, 1956) [2]. Barges and watercrafts were deployed where swamps and tidal waters pose obstacles to free movement.

The port of Port Harcourt was the second largest port in Nigeria in the 1950s, the Calabar port was also very busy in terms of import-export businesses. After the opening of the port of Port Harcourt in 1913, the Enugu railway line was completed in 1916 with berth dredged to enable colliers load for export through Port Harcourt port (Nimasa e-library, n.d) [5]. It is, therefore, given that most of the Eastern regional economic activities were carried through the ports of Calabar and Port Harcourt.

To facilitate the smooth operations of all the economic activities taking place in the Eastern region, the NCNC-led regional government setup two entities: the Eastern Nigeria Marketing Board and the Eastern Nigeria Finance Corporation (Information Service, 1956) [2]. It is not surprising that the economy of the Eastern region of Nigeria used to excel beyond being the fastest developing economy among other regions in the country, but the fastest developing economy in Africa (Itodo, 2017) [6] The achievement of the Eastern region did not diminish the fact that the Western region economy was performing very well, and the rest of the regions were performing at their pace.

The state of the political and economic condition of the Igbo people has raised some public debate on how best to address what has been characterized as marginalization. The proposed solutions from the perspective of the Igbo people fell on two flanks: 1) those that call for restructuring, and 2) those that advocate for outright separation from Nigeria. It is true that the founding fathers of Igbo extraction led by Nnamdi Azikiwe were nationalists. Azikiwe advocated for the in- 
violability of Nigeria, arguing that the potential strength of Nigeria to achieve economic and political success lies with its unity (Azikiwe, 1953) [7], albeit, a relationship that honors equality and merit.

Following the advent of the military incursion into the political sphere, and the subsequent Nigeria Biafra civil war, the Nigeria government, dominated with the Northern military and its Southwest partners, begun a deliberate policy of chipping away the rights of the Igbo people. The deliberate action includes excluding them from mainstream political activities and commensurate positions fit for their counterparts from other regions, particularly, those from the northern region. This study will X-ray the causes that impact political and economic situation of the Igbo people post-civil war.

\section{Study Approach}

The research approach for this study will be through historical research which is one of the components of qualitative research method. The historical approach allows the researcher to delve into the past events in order to draw a conclusion through analysis. Hence, this study shall incorporate examination of archival materials where the relevant records of the economic and political development were housed. The researcher would also make use of books, journals, magazines, and various newspaper publications. These sources already in the public domain will be synthesized to extract the unvarnished outcome. The multiple sources of data collection approach will help to eliminate bias, thus, ensure the validity of this study.

\section{Literature Review}

\subsection{Lack of Rehabilitation after the Civil War}

General Gowon promised to rehabilitate and reintegrate the defunct Eastern region which its infrastructure was devastated during the civil war back to the country on equal footing, hence, the slogan: "No victor, no vanquished" (Gowon, 2014) [8]. In that spirit of oneness, General Gowon's military government decreed the policy of Reconciliation, Reconstruction, and Rehabilitation (3Rs) for the defeated Eastern region (Udeajah, 2017) [9]. The policies were merely cosmetic in since they were never actually carried out, while, such policy as the "abandoned property policy" was pursued vigorously (Obi-Ani, 2009) [10]. The consequence was not only economical, but a deliberate strategy designed to weaken the relationship between the Igbo people, and other minority ethnic groups of the Eastern region.

\subsection{Twenty Pounds Flat Fee Refund}

Several policies decreed into law became albatross of the Igbo nation's progress. Saro-Wiwa (2012) [11] wrote that even though the Igbos were reintegrated into society, they continued to face economic discrimination. The $£ 20$ flat rate policy for any amount any Biafran who wishes to exchange his old currency was a deli- 
berate policy to keep them from recovering from the economic devastation. Aduba (2017) [12] argued in The Will newspaper, that Nigeria government deliberately imposed the $£ 20$ flat rate policy without any circumspection.

\subsection{Indigenization Decree}

The promulgation of the Nigerian Enterprises Promotion Decree of 1972, also known as Indigenization Decree, was not done with the accommodation of Igbo interest. The government enacted the policy when the Igbo people were at the weakest economic point just after they have emerged from the civil war (Obi-Ani, 2009) [10]. The implication was that the other ethnic groups were able to participate in purchasing shares of those blue-chip companies that the Nigeria government decided to appropriate.

\section{Manipulated Population Census}

There were several instances of the Nigeria census exercises found to be less than desirable. The need to maintain a very high population figure advantage by certain regions over the others was intense. That notwithstanding, even the demographers found the 1973 population census incredibly manipulated (Metz, 1991) [13]. The census exercise confirmed that Nigeria's population grew by 44 percent in 10 years, while, Northern Nigeria's population jumped to 64 percent compared to 53.7 percent in 1963 (Metz, 1991) [13]. The bloated population advantage has consequences for the creation of states, local governments, and the sharing of accrued revenues at the center since in practice, Nigeria runs a unitary system as against the federal system on paper.

\section{Federal Character Principle}

Federal Character principle is enshrined in the 1999 Constitution, but its first introduction was the 1979 Constitution. Section 14 (3) and (4) of the 1999 Constitution provide for the equitable distribution of positions in the military, paramilitary, police, all other security institutions, public service, parastatals, and publicly owned companies (Constitution of the Federal Republic, 1999) [14]. The plain accommodation of the principle as it ought to be applied has not always worked according to the dictates of the constitution, primarily, when it comes to placing the Igbo people in certain positions.

The President Buhari administration has been the worst offender that he had been called out for his insensitivity to other ethnic groups when making appointments. According to Senator Abaribe, the incumbent Nigeria President, General Buhari has willfully ensured that the Southeast zone was not included in the National Defence Council and the National Security Council (Busari, 2018) [15].

\section{Creation of States and Local Government Areas}

The creation of states and local government areas were deliberately made to fa- 
vor Northern Nigeria. The Southeast zone is the only political zone among the six political zones that has only five states, while, the rest of the other zones have six states each (Aribisala, 2015) [16]. Aribisa1a [16] concluded that this has consequently led to Southeast being the only zone with the least amount of revenue allocation in the Federation. Former Governor of Anambra state, DrEzeife, and OluFalae, the former Secretary to the Government of the Federation argued that the creation of more states and local governments in favor of the Northern states was an injustice against their zones, Southeast and Southwest, respectively (Kalu, 2017 [17]; Eya, 2017 [18]).

Both writers observed that the injustice argued by Ezeife and Falaeis based on the lopsided size of revenue allocations from the federal government that goes to the northern states. OluFalae pointed out that Lagos state which is densely populated, used to have a uniform number of local governments (precisely 20 LGAs) with Kano state (Eya, 2017) [18]. Falae argues that while Lagos has been made to retain the same number of local government areas, Kano has grown to 77 LGAs.

The Kano state in 1991 was divided into two states, with Jigawaas the new state out of the old Kano state (Adisa, 2011) [19]. It is not only the lopsided revenue allocations being channeled to the northern region that is perceived as injustices, but the political inequities acutely manifest in addressing the national issues. Take, for example, Nwabufo (2019) that in "In 2015, the south-east had no representation in the leadership of all the arms of government. This was rationalized at the time with a bogus claim, 'the zone did not produce any ranking senator or member of the house of representatives on the platform of the APC" (para. 7) [20]. The interests of the Southeast are never adequately protected because the states and LGAs created by military fiat to the detriment of Southeast hollows their ability to be effective. The enumerated consequences of States and LGAs creations were some of the reasons for the call to restructure Nigeria.

\subsection{Deliberate Underuse of Seaports}

There is a well-considered perception that the seaports within the Igbo axis are deliberately underused when one considers the fact that Port Harcourt port was a bustling port prior to Nigeria independence, up until Nigeria Biafra civil war to (Information Service, 1956) [2]. The Port Harcourt port was the second largest port in the country commissioned in 1913 as with Lagos port (Nimasa e-library, n.d) [5]. The Calabar port was equally busy handling exports and imports. Today, Nigeria's Lagos seaports are fully congested; lives of residents, business owners, and motorists are impacted negatively due to conditions at the ports. The Pointer (2019) observed that "a recent report based on estimates by terminal operators has it that more than 2 million twenty tons equivalent units (TEUs) of laden containers are awaiting clearance at Lagos seaports" (para. 1) [21]. The Lagos ports handle over 80 percent of the cargoes that enter the country (The Pointer) [21]. In spite of these problems, the federal government had refused to 
dredge the river Niger, improve the Calabar and Warri ports, etc., or make it friendly to use Port Harcourt to ease the economic waste arising from the concentration of activities in Lagos ports.

\subsection{Lack of International Airport}

The Igbo people are found in every nook and cranny of Nigeria, and virtually, in all parts of the world. The Igbo people are constantly on the move, both domestically and internationally. Most of the times, they must travel to Lagos or Abuja, before they could connect any direct international flights. It was in 2013 that the President Good luck administration completed the facilities at Enugu airport, now Akanu Ibiam International airport, which enabled the first international flight led by Prince Arthur Eze (Edike, 2013) [22]. He said on arrival at Enugu airport: "Look at me, I flew from Senegal to Enugu for four hours non-stop. I don't need to go to Lagos or Abuja to catch direct flight again to Europe or Senegal. I can now go from my house to any place of choice" (Edike, 2013) [22].

It is worth noting that the Federal government has not invested in upgrading the facilities at Enugu airport to international airport status. The runways are very bumpy without the approach lights; there are no water supplies, the cooling systems are not working, etc. (Mikairu and Agbo, 2019) [23]. The Southeast governors have raised the alarm about the state of the airport, and why the contract that had been awarded for the airport by the present government has not reflected at the airport (Mikairu and Agbo, 2019) [23].

The federal government has recently announced that it will shut down the airport for security reasons (Aliyu, 2019) [24]. The announcement was not well received by the people of Southeast both on the chat rooms and mainstream media. The Ohanaeze Ndigbo asked the government not to embark on such action as the timing is not right, and it will impact negatively on the development of the Igbo economy (Olokor, 2019) [25]. Mr Chiedozie Orizu, the spokesperson for Ohanaze Youth leader, Arthur Obiora, advised the federal government that such move will not augur well for the development of the Igbo land (Okeke, 2019) [26]. There had not been anything to show that the contract award for the Enugu airport has reflected on it yet.

\section{Other Impediments}

Other impediments are directed against the Igbo people. Some of the barriers are excessive police checkpoints directed against the Igbo people and businesses, and Customs personnel harassment of Igbo people's business interests. The use of touts to harass and collect illegal levies from the Igbo shops with the active support of some politicians in places such as Lagos state.

The Igbo people suffer excessive extortion and harassment at the ubiquitous police checkpoints both within their homeland and routes leading to the Southeast. The harassment is more intense during the festive periods when the people of Southeast visit their families (Okolie, 2017) [27]. Mr. Peter Obi, the former 
Governor of Anambra, state condemned the activities of the Customs on the highway, particularly, on roads leading to Igbo heartland, where he observed numerous Customs checkpoints from Ore to Onitsha (Olowookere, 2016) [28]. The extortion by the Customs on containers that had been cleared at the ports on roads leading to the Southeast calls to question the Buhari's professed fight against corruption (NAN, 2016) [29].

\section{Conclusions}

The economic and political marginalization of the Igbo people is not subtle; it is an active and deliberate effort designed by the federal government to checkmate their ascendency or recovery from the devastation of the Nigeria Biafra civil war. An objective analysis of the pre-civil war period of 1967 would lead one to the conclusion that the Eastern region was the leader in the area of economic activity beyond the shores of Nigeria. The Eastern region leaders did not only provide robust opposition against the British colonial masters but insisted on a strong Nigeria without discrimination.

Just before the civil war, the military government under General Gowon had begun the fragmentation process of the Eastern region to weaken the Igbo ethnic group. The end of the civil war in 1970 led to the period of unfulfilled economic rehabilitation, a punitive refund of $€ 20$ pounds flat rate, the introduction of the Nigeria Enterprise Promotion Decree of 1972 (Indigenization Decree), and quota system, etc. It is important to note that these laws were ushered in during the military government or regime, where not one Igbo person was accommodated in the Supreme Military Council.

\section{The Way Forward}

Several approaches that could be applied by the federal government or the States could do to address the political and economic marginalization of the Igbo ethnic group in Nigeria. Some of the suggestions that may help resolve the anomalies are:

1) Restructure: There is the need for the Nigeria government to agree to wholesome restructure without reservation. The restructuring would be ideal for returning the country to the era when the regions manage their economic and political affairs. During the period of the regional government, all the regions thrived at their respective paces.

2) Shared Values: The previous demand for restructuring the country notwithstanding, the Igbo community must identify those that share the same values with them, and persuade them to forge partnerships to resist unwieldy policies from the federal government.

3) Integrated Development: The governors of the Southeast must, as a matter of urgency, promote integrated infrastructural development such as:

a) Roads: The Southeast governments should align their plans for the construction of roads to maximize the efficiency of moving human and goods that 
are based on road transportation.

b) Rail: The geopolitical zone needs a dedicated rail network to facilitate easy movement of human and products within the region. The same rail system will encourage more movement of products from the geopolitical zone to other zones.

c) Water Ways Transport: Before the civil war, the Eastern region used to have an advanced waterways transportation system using varieties of waterways vehicles. They should introduce water vehicles that are technologically advanced and efficient.

d) Energy Development: The Southeast governments should integrate energy development in the zone to support the economic advancement in the geopolitical area The Southeast lacks sincere public electricity support from the federal government since the end of the civil war. The Oji power generating facility was left to rot, while the federal government sustained various power projects in other parts of Nigeria, particularly, the northern region, albeit, the disproportionate revenue the region generates for the sector.

4) Close Agricultural Relationship: The various Southeast governments should adopt synergistic agricultural industries based on comparative advantage.

5) Quality Educational Hub: The Southeast should have an integrated quality educational system. In addition to raising the quality of education delivery in the geopolitical zone, the various state governments should make research and technological development the cornerstone of support to the school system. They should liaise with the Igbo people in Diaspora to lend their skills to the zone, as well as solicit institutional and practical support for the geopolitical zone.

The researcher believes that the study's outcome will add value to the body of literature, help the political activists, and finally, will be of benefit to the students of political science and public administration. The researcher invites other scholars to conduct further studies into the phenomenon.

\section{Conflicts of Interest}

The author declares no conflicts of interest regarding the publication of this paper.

\section{References}

[1] University of Central Arkansas (2019) Nigeria (1960-Present). Political Science. https://uca.edu/politicalscience/dadm-project/sub-saharan-africa-region/nigeria-19 60-present/

[2] Information Service (1956) Eastern Region (Nigeria). Enugu, Eastern Nigeria Information Service, Enugu.

[3] Ministry of Commerce, Eastern Region (Nigeria) (1966) Investment Opportunities in Eastern Nigeria. Government Printer, Enugu.

[4] Van Buer, F. (1968) The Structure and Administration of the Eastern Nigerian Tax System. University of Illinois at Urbana-Champaign. Urbanałand Champaign, IL. 
[5] Nimasa e-Library (n.d.) History Background: The History of Port Development in Nigeria. http://www.nimasaelibrary.com/PDFs/133214596496078.pdf

[6] Itodo, Y. (2017) Igbo Marginalization, a Reality that Bothers on Exclusion-Ekweremadu. Daily Post.

http://dailypost.ng/2017/04/28/igbo-marginalization-reality-bothers-exclusion-ekw eremadu/

[7] Azikiwe, N. (1953) Speech on Secession. Cambridge University Press, Cambridge.

[8] Gowon, Y. (2014) Civil War: Why We Declared 'No Victor, No Vanquished'. Blueprint.

https://www.blueprint.ng/civil-war-why-we-declared-no-victor-no-vanquished-gow on/

[9] Udeajah, G. (2017) Failure of Gowon's Three Rs, Cause of Separatist Groups. The Guardian. https://guardian.ng/politics/failure-of-gowons-three-rs-cause-of-separatist-groups/

[10] Obi-Ani, P. (2009) Post-Civil War Political and Economic Reconstruction of Igbo Land, 1970-1983. Great AP Publishers Ltd., Nsukka, Nigeria.

[11] Saro-Wiwa, N. (2012) There Was a Country: A Personal History of Biafra by Chinua Achebe-Review. The Guardian.

https://www.theguardian.com/books/2012/oct/05/chinua-achebe-there-was-a-count ry-review

[12] Aduba, B.O. (2017) Opinion: The Nigerian Twenty Pounds Policy of the Seventies' Implementation. The Will.

https://thewillnigeria.com/news/opinion-the-nigerian-twenty-pounds-policy-of-the -seventies-implementation/

[13] Metz, H.C. (1991) Nigeria: A Country Study: The Society and Its Environment: Census. Library of Congress. http://countrystudies.us/nigeria/

[14] Constitution of Federal Republic of Nigeria (1999) Chapter IV: Fundamental Rights. Constitution of Federal Republic of Nigeria http://www.nigerialaw.org/ConstitutionOfTheFederalRepublicOfNigeria.htm

[15] Busari, K. (2018) Buhari Deliberately Sidelined South East in Security Appointments-Abaribe. Premium Times.

https://www.premiumtimesng.com/news/top-news/292015-buhari-deliberately-side lined-south-east-in-security-appointments-abaribe.html

[16] Aribisala, F. (2015) Root Causes of the Biafra Struggle. Vanguard. https://www.vanguardngr.com/2015/12/root-causes-of-the-biafra-struggle/

[17] Kalu, V. (2017) Ndigbo Should Not Allow Soldiers Immunise Their Children Ezeife. Sun News Online.

https://www.sunnewsonline.com/ndigbo-should-not-allow-soldiers-immunise-their -children-ezeife/

[18] Eya, W. (2017) We Must Restructure before 2019. Falae, 49.

[19] Adisa, A. (2011) Kano State-“Center of Commerce”. Come to Nigeria Magazine. https://www.cometonigeria.com/region/north-west/kano-state/

[20] Nwabufo, F. (2019) Southeast Excluded from National Assembly Leadership a Repeat of Azikiwe, Awolowo's Mistakes. Sahara Reporters.

http://saharareporters.com/2019/03/16/southeast-excluded-national-assembly-leade rship-repeat-azikiwe-awolowos-mistakes-fredrick

[21] The Pointer (2019) Cargo Congestion at Lagos Ports. The Pointer.

https://thepointernewsonline.com/?p=55662 
[22] Edike, T. (2013) First International Flight Lands in Enugu Airport. Vanguard. https://www.vanguardngr.com/2013/08/first-international-flight-lands-in-enugu-ai rport/

[23] Mikairu, L. and Agbo, D. (2019) Enugu: Another Shame of Nigerian Airports. Vanguard.

https://www.vanguardngr.com/2019/05/enugu-another-shame-of-nigerian-airport/

[24] Aliyu, A. (2019) FG to Shut Enugu Airport for Safety Reasons. Daily Trust. https://www.dailytrust.com.ng/fg-to-shut-enugu-airport-for-safety-reasons.html

[25] Olokor, F. (2019) Enugu Airport: Ohanaeze Ndigbo Kicks against Closure. Punch. http://punchng.com/enugu-airport-ohanaeze-ndigbo-kicks-against-closure/

[26] Okeke, A. (2019) Ohanaeze Ndigbo Outcry Closure of Enugu Airport. Nigeria Pilot. http://nigerianpilot.com/ohanaeze-ndigbo-outcry-closure-of-enugu-airport/

[27] Okolie, A. (2017) As the Igbo Decry Harassment from the Nigeria Customs Service. This Day.

https://www.thisdaylive.com/index.php/2017/01/01/as-the-igbo-decry-harassmentby-nigeria-customs-service/

[28] Olowookere, D. (2016) Customs Harassing Igbo Travellers-Obi. Business Post. https://businesspost.ng/2016/12/21/customs-harassing-igbo-travellers-obi/

[29] NAN (2016) Customs, Police Extorting Us-South East Traders. The Punch Newspapers. https://punchng.com/customs-police-extorting-us-south-east-traders/ 